\section{Thrombosis and Anticoagulant Therapy}

Edited by W. WALKER. Pp. 106, illustrated. University of St. Andrews. Distributed by E. \& S. Livingstone, Edinburgh and London. 1961. 17s. $6 d$.

The popularity of the subject of thrombosis and anticoagulant treatment is shown by the publication of the proceedings of two international symposia on the subject which took place within a month in Dundee and London. In the first there participated a selected panel of experts invited by Dundee University. The publishers are to be congratulated on the speed in which they have produced the records of this meeting and for the economical cost of the publication.

The proceedings are, however, somewhat of a disappointment to the ordinary medical reader who may be mislead by the rather presumptuous title into thinking this is a practical manual on the subject. The approach is very academic and, apart from an excellent paper by Smith of Glasgow on anticoagulant therapy in peripheral vascular disease, there is little which is new to the general reader.

The expert coagulationist will also be disappointed in the lack of original material and the uncritical reiteration of the merits of the thrombotest on the control of treatment. An exception must be made for the interesting paper by the Warsaw workers Niewiarowski and Wegrzynowicz on the anticoagulant action of heparin.

\section{Virus Meningo-Encephalitis}

Ciba Foundation Study Group, No. 7. Edited by G. E. W. Wolstenholme, O.B.E., M.A., M.B., M.R.C.P., and Margaret P. Cameron, M.A. Pp. viii +120 , illustrated. London: J. \& A. Churchill. 1961. I $2 s .6 d$.

The discovery of the virus has not had the same impact on clinical medicine as did the discovery of bacteria. It is in the epidemiological field that study of the virus has been most helpful. The reasons for this seem partly technical, for the isolation and identification of a virus from a clinical case is a complex and time-consuming process, and an answer cannot usually be expected until the clinical diagnostic problem is already retrospective. Because of this, many clinicians have a blind spot with regard to virology, a scotoma which this little book will go a long way to remove. A group of virologists and clinicians met in the usual manner of CIBA symposia and discussed the present situation regarding virology in meningo-encephalitis. A clear statem ent of the methods involved enables the clinician to gain an insight into the problems of the virologist and the various clinical contributions indicate what are the current outstanding problems to the solution which clinicians seeing these cases might contribute. The book makes pleasant reading and can be greatly recommended.

\section{Toxicity of Industrial Metals}

Ethel Browning, M.D. Pp. vii $+325+$ index (14 pp.). London: Butterworths. 196r. 50s.

The subject matter of this book is marshalled in an orderly manner and, indeed, the whole is arranged in a way that makes reference easy. The book, in fact, seems designed mainly or entirely as a book of reference. It is certainly not an easy book to read. Even the text itself is not very readable, largely owing to the reference to the literature, which thickens it. This, of course, means that the bibliography is an extensive one, which is another benefit to the user of the book.
One may say that the book is a reference book which will enable any doctor to gain a quick basic understanding of the industrial uses and toxic effects of a particular metal and will allow him to study the matter in detail should he wish or require to do so. The list of industrial metals dealt with is a pretty complete one but the word 'metal' is strictly adhered to, and strictly interpreted, as, indeed, the author states clearly in her preface.

The book will be valuable to those who need it and the price is a reasonable one. It is an attractive, well-bound volume, the printing is clear and the paper is adequate.

\section{The Nature of Sleep}

A Ciba Foundation Symposium. Edited by G. E. W. WolsTENHOLME, O.B.E., M.A., M.B., M.R.C.P., and M. O'ConNor, B.A. Pp. xii +416 , illustrated. London: J. \& A. Churchill. 196r. 50s.

Here we have another of the well-known Ciba symposia in which a group of experts gather to discuss a particular topic, this one being under the chairmanship of Sir John Eccles. The bulk of the book is concerned with the electrophysiology of neurons, their activation and deactivation, and their synchronization and desynchronization. Inevitably the reticular formation receives special attention. These subjects are all dealt with by experts working in the field; hence this is in reality an up-to-date review of the physiology of the neuron.

More germane to the nature of sleep itself in man are contributions on sleep during polar expeditions and on the nature of dreaming. As the chairman points out, a conspicuous lack is of any discussion of the metabolic basis of the changes in neural activity which lead to sleep and wakefulness and why such changes must needs occur. This is not due to the absence of awareness on the part of the contributors of its importance, but to the almost complete lack of knowledge about this field which exists at the present time. Maybe in a few years' time another symposium will take place to fill this gap.

\section{Chemistry of Enzymes in Cancer}

Franz Bergel, D.PHIL.NAT., D.SC., F.R.S. Pp. xi + 122, illustrated. Springfield, Illinois: Charles C. Thomas. Oxford: Blackwell Scientific Publications. 1961. $44 s$.

The basic thesis of this monograph is that metabolic and enzymic abnormalities exist as a cause or characteristic of cancer. Professor Bergel begins by giving his version of the three main hypotheses of cancer metabolism, particular emphasis being placed on the ' deletion' hypothesis.

Evidence is presented for the existence in experimental animal tumours of a deficiency of catabolic enzymes in nucleotide metabolism, leading to increased potential for nucleic acid synthesis and cell division and of a block against glycogen storage in carbohydrate metabolism, glucose being utilized for energy production. In addition, there appears to be reduced lipid production together with alterations in co-enzyme levels.

The author then discusses the ways in which enzyme activity may be influenced by exogenous means, particularly by the use of inhibitors and antagonists, and reports on the use of selected enzymes and co-enzymes in carcino-chemotherapy in the experimental animal and, in one instance, in man.

Written by an international authority in the field of cancer research, this monograph will appeal more particularly to the biochemist working in this field rather than to the practising clinician. 